\title{
Performance and economic indicators of a large scale fish farming in Mato Grosso, Brazil ${ }^{1}$
}

\author{
Adriana Fernandes de Barros ${ }^{2}$, Maria Inez Espagnoli Geraldo Martins ${ }^{3}$ \\ ${ }^{1}$ Financed by Fundação de Amparo a Pesquisa do Estado de Mato Grosso. \\ 2 Centro de Aquicultura da Universidade Estadual Paulista Julio de Mesquita Filho - CAUNESP. Via de Acesso Paulo Donato Castellane, \\ s/n-14884-900, Jaboticabal, SP, Brasil. Universidade do Estado de Mato Grosso, Departamento de Zootecnia, Pontes e Lacerda, MT, Brasil. \\ 3 Departamento de Economia Rural e Centro de Aquicultura.
}

\begin{abstract}
Performance and economic indicators of a large scale fish farm that produces round fish, located in Mato Grosso State, Brazil, were evaluated. The 130.8 ha-water surface area was distributed in 30 ponds. Average total production costs and the following economic indicators were calculated: gross income (GI), gross margin (GM), gross margin index (GMI), profitability index (PI) and profit (P) for the farm as a whole and for ten ponds individually. Production performance indicators were also obtained, such as: production cycle (PC), apparent feed conversion (FC), average biomass storage (ABS), survival index (SI) and final average weight (FAW). The average costs to produce an average $2.971 \mathrm{~kg} \cdot \mathrm{ha}^{-1}$ per year were: $\mathrm{R} \$ 2.43$, R\$ 0.72 and R\$ 3.15 as average variable, fixed and total costs, respectively. Gross margin and profit per year per hectare of water surface were R\$2,316.91 and R\$ 180.98, respectively. The individual evaluation of the ponds showed that the best pond performance was obtained for PI 38\%, FC 1.7, ABS $0.980 \mathrm{~kg} . \mathrm{m}^{-2}$, TS 56\%, FAW $1.873 \mathrm{~kg}$ with PC of 12.3 months. The worst PI was obtained for the pond that displayed losses of 138\%, FC 2.6, ABS $0.110 \mathrm{~kg} \cdot \mathrm{m}^{-2}$, SI $16 \%$ and FAW $1.811 \mathrm{~kg}$. However, large scale production of round-fish in farms is economically feasible. The studied farm displays favorable conditions to improve performance and economic indicators, but it is necessary to reproduce the breeding techniques and performance indicators achieved in few ponds to the entire farm.
\end{abstract}

Key Words: costs, income, ponds, profitability, round fish

\section{Introduction}

Fish farming is wide spread in Brazil and differs only with respect to species, production systems and volumes. The Brazilian fish production in 2007 was 210,644 tons and increased to 337,353 tons in 2009, an increase of $60 \%$. The Midwest, which is currently responsible for the 3rd largest continental aquaculture production, produces mainly fish from the genus Colossoma, Piaractus and their hybrids, and the state of Mato Grosso is responsible for $50.9 \%$ of the region production (MPA, 2010).

In Mato Grosso, fish-farming is rising within the agricultural sector and has favored the development of other industries, such as animal feed, equipments, fish processing, transport of live fish, among others. According to Barros et al. (2011), in Mato Grosso, fish farms with more than 50 ha of water surface are classified as large scale production, and farms in that state are, in general, larger than the national average.

However, literature about tilapia cultivated mostly in net cages (Ayrosa et al., 2011; Firetti \& Sales, 2007; Furlaneto et al., 2006; Scorvo Filho et al., 2006; Vera-Calderon \&
Ferreira, 2004), and some native species, especially pacu Piaractus mesopotamicus in fishponds (Barros et al., 2010; Furlaneto \& Esperancini, 2009; Izel \& Melo, 2004; Jomori et al., 2005; Melo \& Pereira, 1994) can be found. No literature was found on the native species cultivated in Mato Grosso, where the geographic, climatic and rearing areas consisting of large farming systems markedly differ from other Brazilian states where, in most cases, fish are reared in smaller ponds.

Due to growing importance of fish farming in this state and in Brazil as well, and the lack of primary updated information regarding its fish-farms, this study aims to establish economic and performance indicators of a large fish farm in Mato Grosso, Brazil.

\section{Material and Methods}

Fish farms in Mato Grosso, Brazil are classified according to water surface area (State Law No. 8464 of 04.04.2006, Article 3) as micro, up to one hectare; small, between 1.1 and 5 hectares; average, between 5.1 and 50 hectares, and large, bigger than 50 hectares (Diário Oficial, 2006). 
Accordingly, the fish farm studied was characterized as large, with 130.8 ha of total water surface area, distributed in 30 ponds. From these, a 24 ha-pond was rented from a neighboring farm for 19 months. Of the cultivated species, 98\% was the round fish Colossoma, Piaractus genus and their hybrids, which were acquired in larval and/or juvenile phases and fed exclusively with commercial extruded feed. Data were collected monthly for 23 months.

Most of the water surface area of the studied fish farm was built by interception of water stream or dam system, as characterized by Martin et al. (1995), because the initial investment is lower.

The water surface of individual ponds varied from 0.5 ha to 24 ha, with 4.5 ha average. The smaller ponds were used as nursery, where the larvae were stocked until they metamorphosed into juveniles. The larger ones were used as grow-out ponds, where feed was supplied using a motor boat.

Rain or well water was supplied by gravity, individually and/or in series. The water renewal was performed only to replace evaporation and infiltration losses. The drainage system consisted of elbows, floodgates and surface spillways, depending on the requirements and conditions of each pond.

Daily control sheets were prepared and filled by the farmer or technical assistant, with detailed information on expenditures, investments, performance variables and information regarding production, harvest and marketing. The experiment took place from January, 2008 to November, 2009. Once a month, the farm was visited to investigate and collect the control sheets. The data were then processed to calculate performance and economic production indicators. Individual control was performed in 10 ponds, where the production cycle was followed from beginning to end. The performance parameters calculated were:

Average stocking biomass: defined as live weight per $\mathrm{m}^{2}$ and expressed as kg.m ${ }^{-2}$; Apparent feed conversion (FC): kg feed consumed per weight gained during the period; Survival rate (SR): $\frac{\text { number of harvested fish }}{\text { numberof stocked fish }} \times 100$, expressed as a percentage; Production cycle: length of production cycle, expressed as months; Average final weight: $\frac{\text { total harvested weight }}{\text { number of harvested fish }}$, expressed as kg.

Total cost (TC) was determined according to methodology described by Martin et al. (1998) and Martins \& Borba (2008). This production cost structure takes into account expenses incurred during the production process, depreciation of fixed capital items, as well as the remuneration or opportunity costs of employed production factors (Scorvo Filho et al., 2004). Total cost is the sum of the variable costs (VC) and fixed costs (FC) .

Data related to expenses, revenue and opportunity cost of the entrepreneur were collected and compiled monthly as cash flow. Depreciation and other opportunity costs were compiled as cash flow only in the last month of the year (December 2008) and data collection (November 2009) proportionally to eleven months.

Total cost was determined according to the following procedures:

Initial capital investment was given by the market value for June, 2009 and adjusted for December, 2007 using the General Price Index - Internal Availability (IGP-DI) from Fundação Getulio Vargas. Actual value was calculated taking into account depreciation and additional accounting useful life.

The item "others" accounted for smaller expenses that were not measured and was assumed to be $10 \%$ of the total invested on improvements, machinery and equipments; Land remuneration was based on the average rental value, usual practice in the region, of $\mathrm{R} \$ 11,125.00$ per month per 106.8 ha of own water surface, which corresponds to real return opportunity of capital invested; Remuneration of the fixed capital considered the mean capital value to be remunerated at $6 \%$ per year, which corresponds to real saving remuneration; Entrepreneur remuneration was determined according to his qualification and opportunity cost in the region, $\mathrm{R} \$ 5,000.00$ per month; Linear depreciation was applied for fixed capital items, with scrap value of zero; Repairs and equipment maintenance rate was assumed to be $5 \%$ per year, based on the initial acquisition price, and $2 \%$ per year based on the initial building price, according to Martin et al. (1995); A rate of $5 \%$ over the amount of actual expenses was also considered to account for eventual expenses; Hired labor varied from one to three minimum wages, depending on the function, social charges, bonus and feeding expenses.

Eventual labor daily rate ranged from $\mathrm{R} \$ 20.00$ to R\$ 40.00 depending on the activities. Family labor and technical services related to the production process were assumed to cost the same as hiring a technician. Fees and taxes considered the costs of farmer registration, environmental clearance for aquaculture and rural land tax (ITR).

To determine total cost per pond, the indirect costs were allocated based on water surface area and production cycle period.

The monthly data were capitalized for November 2009, as follows: $\mathrm{FV}=\mathrm{VP}(1+\mathrm{i})^{\mathrm{n}}$ 
$\mathrm{FV}=$ future value (2009/November); $\mathrm{VP}$ = value of item costs in each month; $\mathrm{i}=$ capitalization rate of $0.5 \%$ per month; $\mathrm{n}=$ number of months $(22,21,20,19 \ldots 0)$.

The $0.5 \%$ monthly rate, which is the real return from the savings account can underestimate the capitalized values, since the monthly nominal rate varies according to $0.5 \%$ plus the change in reference interest rate. However, since costs and revenues were also capitalized the same way, this procedure does not affect the gross margin and profitability rates.

The following indicators were used in the profitability analysis:

Gross revenue (GR): revenue that resulted from sales, i.e., $\mathrm{GR}=\mathrm{q} * \mathrm{p}$; $\mathrm{q}$ is the quantity sold and $\mathrm{p}$ is the selling price; Profit $(\mathrm{P})$ : $\mathrm{P}=\mathrm{GR}-\mathrm{TC}$, where TPC is ; Gross margin (GM): GM = GR - VC; Gross Margin Index (GMI): is the percentage of contribution over gross income, i.e., the fraction of the sales that contributes to offset fixed costs, i.e., GMI $=\frac{\mathrm{GR}-\mathrm{VC}}{\mathrm{GR}} \mathrm{x} 100$; Profitability Index $(\mathrm{PI})$ : it is the relationship between Gross Revenue and Profit Revenue and explains what percentage of revenue from product sales is profit, i.e., $\mathrm{PI}=\frac{\mathrm{GR}-\mathrm{TC}}{\mathrm{GR}} \times 100$; average variable (AVC), fixed and total costs: refer to the production cost per unit $\left(\mathrm{R} \$ \cdot \mathrm{kg}^{-1}\right)$, expressed as the ratio between cost and quantity produced. Equilibrium point (EP): minimum production level needed to offset total costs, at a given selling price (p), expressed as $\mathrm{kg}$. (ha.yr) $)^{-1}$, i.e., $E P=\frac{F C}{p-A V C}$

\section{Results and Discussion}

Although there are few studies in the literature that extrapolate their data to larger fish farms, none match the size of the studied fish farm. Therefore, the comparison of the results obtained in this study is difficult and highlights the lack of information on fishery projects of such magnitude.

The total investment was $\mathrm{R} \$ 1,587,920.40$, i.e., $\mathrm{R} \$ 14,868.17 \mathrm{ha}^{-1}$ of water surface; however, this value can be lowered to $\mathrm{R} \$ 13,106.26 \mathrm{ha}^{-1}$, if the capitalization rate of items that are used for other productive activities is taken into account (Tables 1 and 2). Of the total, 71.4\% was spent in pond construction and only $28.6 \%$ was used to purchase machinery, equipments and to build other facilities to support the activity.

The largest expense was the construction of the fish ponds, which corroborates the study by Andrade et al. (2005), who also reported that $70.8 \%$ of the capital was invested in the construction of fishponds. Therefore, a study to determine the geological and topographical features of the site where the excavated ponds are going to be built is of fundamental importance, since this can avoid future substantial loss. According to Martin et al. (1995) building the fish ponds by damming water systems costs $60 \%$ less compared with fish ponds built by derivation. This difference will directly reflect on fixed costs and consequently, the total cost.

The largest shares of the costs were spent on feed and labor: $71 \%$ and $11 \%$, respectively (Table 3). A similar result was reported by Scorvo Filho et al. (1998) while working with round fish also reared in excavated fish ponds in São Paulo. Martin et al. (1995) stated that feeding is the most

Table 1 - Investments made to improve the operations of a large fish farm with 106.8 ha-water surface ${ }^{1}$

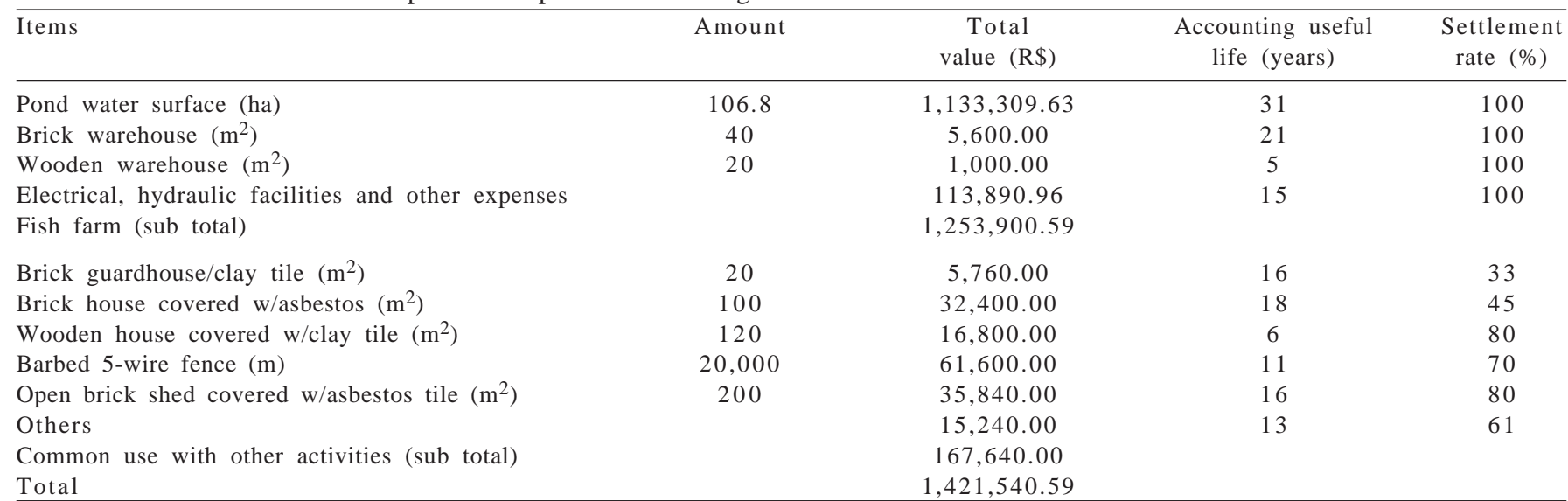

${ }^{1}$ Values in Brazilian reais, capitalized in December, 2007.

$1 \mathrm{US} \$=\mathrm{R} \$ 1,771$ 
Table 2 - Machinery and equipment investment of a large fish-farm with 106.8 ha-water surface ${ }^{1}$

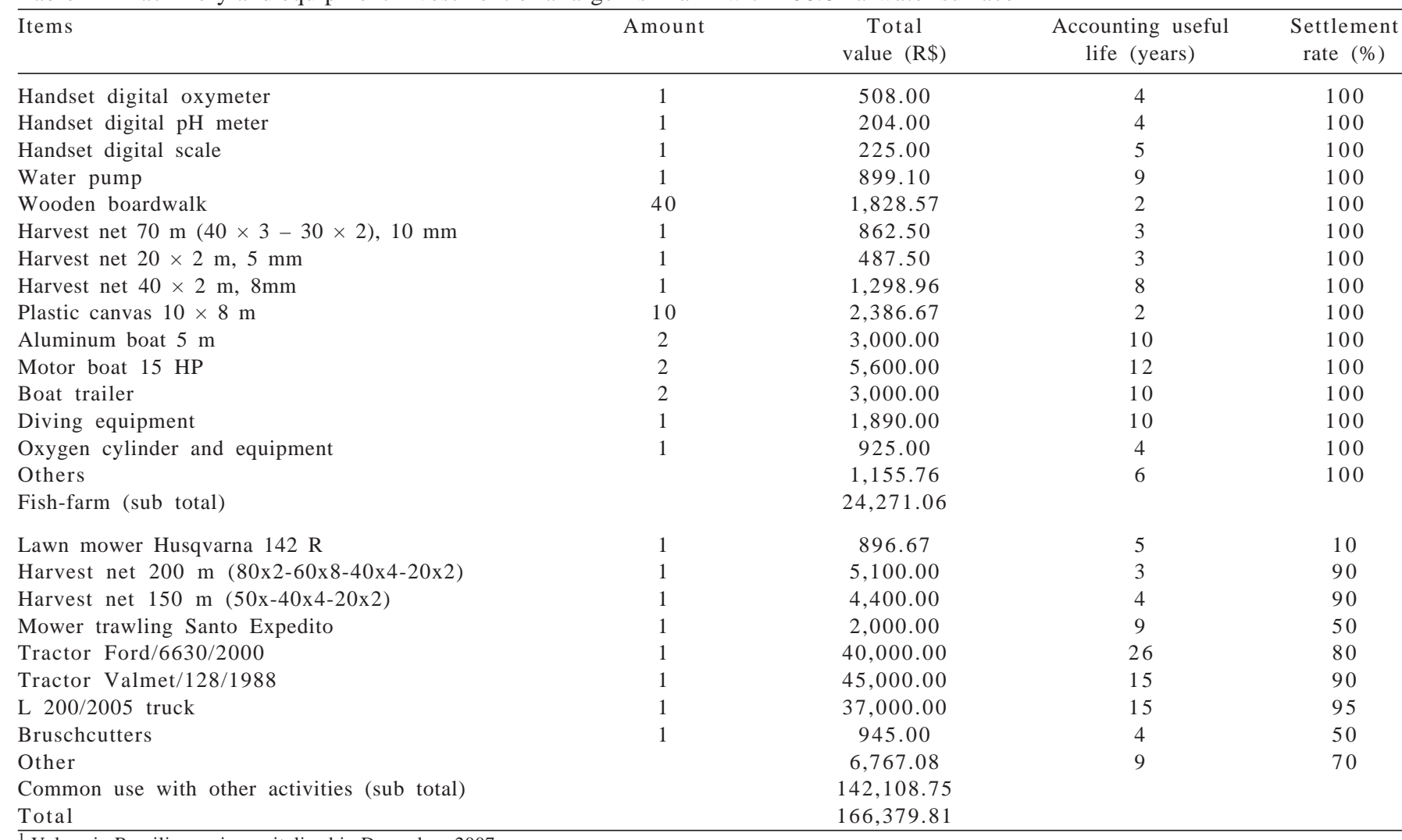

${ }^{1}$ Values in Brazilian reais, capitalized in December, 2007.

$1 \mathrm{US} \$=\mathrm{R} \$ 1.771$.

Table 3 - Total cost of 744,790 kg of fish cultivated in 130.8-ha-water surface, in the 2008/2009 season (23 months)

\begin{tabular}{lcc}
\hline Specifications & Total value $(\mathrm{R} \$)^{1}$ & Participation (\%) \\
\hline Hired labor & $188,518.94$ & 11 \\
Fuel & $55,857.98$ & 3.2 \\
Administrative expenses & $7,348.66$ & 0.4 \\
Larvae and juveniles & $37,212.92$ & 2.1 \\
Extruded feed & $1,238,229.40$ & 71 \\
Fees and taxes & $10,551.73$ \\
Rent of a 24 ha-water surface pond & $51,834.06$ \\
Eventual expenses & $79,477.68$ \\
Maintenance & $15,540.73$ \\
Repairs & $68,241.96$ \\
Effective operational cost & $1,752,814.05$ \\
Technical and administrative family labor & $60,776.01$ & 3.0 \\
Variable cost & $1,813,590.06$ & 4.5 \\
Depreciation & $121,880.73$ \\
Pond remuneration & $270,453.24$ \\
Interest on fixed capital & $21,590.55$ \\
Entrepreneur remmuneration & $121,552.02$ \\
Fixed cost & $535,476.53$ \\
Total cost & $2,349,066.59$ & 3.9 \\
\hline
\end{tabular}

${ }^{1}$ The amounts were capitalized for November, 2009 at a $0.5 \%$ monthly rate.

1 US\$ $=$ R\$ 1.771 .

important variable of the costs upon which the producer must act, since improving feeding efficiency will lower production costs and at the same time yield better performance indicators.

Over the studied period, fish production was $744,790 \mathrm{~kg}$, with mean live weight of $2 \mathrm{~kg}$, which, based on the amount of fish sold, resulted in average total cost of $\mathrm{R} \$ 3.15$ per kilo of fish. The average selling price for large commercial plants in the area was $\mathrm{R} \$ 3.21$ per kilo and reached up to $\mathrm{R} \$ 4.59$ per kilo; however, this price is achieved when fish is sold directly to the consumer, restaurants and fish markets, in smaller amounts and without sanitary inspection. 
Barros et al. (2011), who conducted a study in the same region and period, reported that only $44.4 \%$ of the fish produced undergo sanitary inspection. Large fish farms in the area sell their fish to large processing plants, a practice carried out by the studied fish farm. Despite the lower selling price offered per kilo of fish by large processing plants, the advantages are the frequency and amount purchased. However, the studied fish farm sold its fish in the lower price range; the GMI and PI indicators were positive (Table 4). Under the studied conditions, the results show that the activity is economically feasible, considering that all production and even opportunity costs were covered.

Scorvo Filho et al. (1998) reported a PI of $28.8 \%$ that reached up to $37.1 \%$ for a fish farm whose production system used aerators. The authors concluded that more technologically advanced farms and therefore, farms that require higher investment are also more profitable.

Table 4 - Performance and economic indicators of a 130.8 ha-water surface fish farm during the 2008/2009 season $^{1}$

\begin{tabular}{lc}
\hline Average sale price $\left(\mathrm{R} \$ . \mathrm{kg}^{-1}\right)$ & 3.21 \\
Productivity (kg.ha-1 year) & 2,971 \\
Average variable cost $\left(\mathrm{R} \$ . \mathrm{kg}^{-1}\right)$ & 2.44 \\
Average fixed cost $\left(\mathrm{R} \$ . \mathrm{kg}^{-1}\right)$ & 0.72 \\
Average total cost $\left(\mathrm{R} \$ . \mathrm{kg}^{-1}\right)$ & 3.15 \\
Gross revenue (R\$.ha ${ }^{-1}$ year) & $9,551.01$ \\
Gross margin (R.ha ${ }^{-1}$ year) & $2,316.91$ \\
Profit (R\$.ha ${ }^{-1}$ year) & 180.98 \\
Gross margin Index (\%) & 24.26 \\
Profitability index (\%) & 1.89 \\
Equilibrium point (kg.ha-1 year) & 2,739 \\
\hline
\end{tabular}

${ }^{1}$ Values capitalized in November, 2009.

1 US\$ = R\$ 1.771.
It should also be noted that structural conditions of the farm themselves implied lower investment per hectare of water surface, and therefore, the minimal productivity requirement (equilibrium point) of $2,739 \mathrm{~kg} \cdot \mathrm{ha}^{-1}$ was lower than the productivity obtained for each individual pond (Table 4). Similar results were reported by other authors working with the same fish species (Furlaneto et al., 2008; Izel \& Melo, 2004; Scorvo Filho et al., 1998; Martin et al., 1995). These results highlight the importance of large scale production, since the activity was profitable even with low productivity.

The performance and economical indicators displayed in Table 5 highlight the differences that exist within them and between different fish farms due to lack of a standard process to breed and cultivate fish, which may result from lack of planning and/or lack of adequate knowledge in the area.

Kubitza (2003) recommended a productivity of 6,500 kg.ha-1 year to obtain fish with final weight between $1.4 \mathrm{~kg}$ to $1.8 \mathrm{~kg}$, if the ponds are not equipped with continuous water renewal, as in the case of the studied farm. The results (Table 5) show that even though productivity was lower in ponds 1, 2, 7, 9 and 10, fish final average weight was higher than the recommended value.

A study conducted in Manaus/AM (Izel \& Melo, 2004) with tambaqui weighing initially $0.1 \mathrm{~kg}$ showed that after a 8-month period, fish final average weight reached $1.8 \mathrm{~kg}$, productivity was $7,200 \mathrm{~kg} \mathrm{ha}^{-1}$, FC 1.2, survival rate $95.2 \%$ and GMI 18.4\%. The comparison of average performance indicators between the two studies (Table 5) shows that for

Table 5 - Individual performance and economic indicators of 10 out of 29 ponds of a large fish farm (130.08 ha-water surface), during the $2008 / 2009$ season

\begin{tabular}{|c|c|c|c|c|c|c|c|c|c|c|}
\hline & \multicolumn{9}{|c|}{ Ponds } & \multirow[b]{2}{*}{10} \\
\hline & 1 & 2 & 3 & 4 & 5 & 6 & 7 & 8 & 9 & \\
\hline \multicolumn{11}{|c|}{ Performance indicators } \\
\hline Cycle (months) & 17.5 & 21.0 & 19.1 & 13.6 & 12.6 & 12.3 & 16.1 & 17.6 & 16.4 & 17.2 \\
\hline Water surface (ha) & 13.5 & 2.9 & 6.0 & 4.2 & 6.0 & 4.4 & 8.4 & 6.5 & 24.0 & 2.0 \\
\hline Productivity (kg.ha-1) & 1,103 & 4,803 & 8,186 & 9,065 & 8,409 & 9,887 & 4,507 & 8,390 & 4,423 & 4,205 \\
\hline Survival rate (\%) & 16.12 & 62 & 45 & 43 & 52 & 56 & 39 & 50 & 44 & 31 \\
\hline Apparent feed conversion & 2.6 & 2.0 & 1.9 & 1.7 & 1.6 & 1.7 & 1.9 & 1.6 & 1.8 & 3.4 \\
\hline Initial body weight (kg) & 0.050 & 0.050 & 0.050 & 0.050 & 0.030 & 0.060 & 0.020 & 0.050 & 0.050 & 0.030 \\
\hline Final body weight (kg) & 1.811 & 2.255 & 2.207 & 2.074 & 1.917 & 1.873 & 1.854 & 2.382 & 2.166 & 1.511 \\
\hline Final stocking biomass $\left(\mathrm{kg} \cdot \mathrm{m}^{-2}\right)$ & 0.110 & 0.667 & 0.819 & 0.906 & 0.841 & 0.989 & 0.451 & 0.839 & 0.442 & 0.421 \\
\hline \multicolumn{11}{|c|}{ Performance indicators } \\
\hline Average variable cost $\left(\mathrm{R} \$ . \mathrm{kg}^{-1}\right)$ & 4.70 & 2.60 & 2.07 & 1.75 & 1.71 & 1.72 & 2.43 & 1.73 & 2.16 & 3.67 \\
\hline Average fixed cost $\left(\mathrm{R} \$ . \mathrm{kg}^{-1}\right)$ & 2.94 & 0.91 & 0.49 & 0.31 & 0.31 & 0.26 & 0.74 & 0.44 & 0.62 & 0.86 \\
\hline Average total cost $\left(\mathrm{R} \$ . \mathrm{kg}^{-1}\right)$ & 7.64 & 3.51 & 2.56 & 2.07 & 2.02 & 1.98 & 3.17 & 2.10 & 2.78 & 4.53 \\
\hline Gross revenue $\left(\mathrm{R} \$ \cdot \mathrm{ha}^{-1}\right)$ & $3,546.17$ & $15,442.69$ & $26,316.24$ & $29,142.08$ & $27,033.17$ & $31,784.94$ & $14,488.94$ & $26,974.64$ & $14,220.92$ & $13,519.53$ \\
\hline Gross margin $\left(\mathrm{R} \$ . \mathrm{ha}^{-1}\right)$ & $-1,642.88$ & $2,971.71$ & 9,353.89 & $13,267.23$ & $12,664.41$ & $14,755.06$ & $3,555.79$ & $12,465.20$ & 4,674.32 & $-1,932.27$ \\
\hline Income $\left(\mathrm{R} \$ . \mathrm{ha}^{-1}\right)$ & $-4,886.44$ & $-1,415.46$ & $5,363.66$ & $10,419.05$ & $10,032.11$ & $12,185.43$ & 199.26 & $8,781.37$ & $1,935.17$ & $-5,532.54$ \\
\hline Gross margin index (\%) & -46 & 19 & 36 & 46 & 47 & 46 & 25 & 46 & 33 & -14 \\
\hline Profitability index (\%) & -138 & -9 & 20 & 36 & 37 & 38 & 1 & 33 & 14 & -41 \\
\hline
\end{tabular}

${ }^{1}$ The values in Brazilian reais were capitalized in November/2009, at rate of $0.5 \%$ per month.

$1 \mathrm{US} \$=\mathrm{R} \$ 1.771$ 
a grow-out period of 16.3 months, most of the performance indicators were worse: average productivity was $6,297 \mathrm{~kg} \cdot \mathrm{ha}^{-1}$, FC 1.73 and survival rate 43.6\%. Despite higher final body weight, indicators point to lower overall performance efficiency in the present study. However, economic indicators such as GMI of $24 \%$ in the 23 -month period (Table 4 ) and average of $40 \%$ for individual ponds (Table 5 ) reached in this study indicate better economic performance. This advantage from the economical view point may be explained by the higher selling price and/or lower variable costs of the present study.

The results (Table 5) show that pond 6 had the lowest FC due to higher stocking biomass and shorter farming period, and both variables affect FC directly. Gomes et al. (2000) also pointed out that stocking biomass has to be considered from an economic point of view, since it influences fish farming costs. Jomori et al. (2005) suggest that the use of the facilities can be optimized mainly by increasing SB, since more densely populated ponds would further increase the productivity of the system and consequently, dilute fixed production costs. This optimization can be seen especially in ponds 3, 4, 5, 6 and 8, where increased productivity diluted costs.

Generally, fish farmed at low stocking biomass display good growth rate, but the production per area is low (Gomes et al., 2000), since the available area is less efficiently used. On the other hand, fish farmed in highly populated ponds usually display lower growth rates (El-Sayed, 2002). The results of this study follow this trend, since the higher stocking biomass observed in pond 6 translated into lower slaughtering weight, despite higher productivity, compared with the less populated ponds 2 , 3, 4, 5 and 9. However, this observation should not be generalized, since lower stocking biomass of ponds 1,7 , 9 and 10 did not imply in higher slaughtering weight, probably due to other influences that were not the focus of this study, such as water quality and whether juveniles were purchased and/or reared on the farm.

Harvesting average weight in ponds 2, 3, 4 and 5 decreased with FC and average costs, thus showing that the lower the final weight, the better the FC, and hence the lower the average costs, which directly influenced total cost. Schmittou (1997) stated that an efficient production does not mean to produce the highest possible weight, but to produce the highest possible weight with the best feed conversion rate in the shortest time possible and with a final weight that is well accepted by the consumer market. This final weight well accepted by the consumer combined with good FC and low average production cost was attained in pond 6, where average weight of $1.870 \mathrm{~kg}$, indicated that the best performance and economic efficiency was reached.

The results of ponds 2, 3, 4, 5 and 6 (Table 5) showed that the higher the final average weight, the higher the average total cost. This can be seen when comparing ponds 6 and 3, where differences of $0.333 \mathrm{~kg}$ and $\mathrm{R} \$ 0.58$ were observed for weight and price, respectively. This result suggests that fish prices should be more flexible, since it allows, if necessary, to lower the price in order to form a more specific market and/or more demanding of larger fish.

These results are important because they show the need to practice different market prices for fish with different weights, this might not happen yet due to lack of both real knowledge of TC and uniformity of the lot, as well. But, it may be noted that in some cases, larger fish are selected for commercialization at harvesting time, thus explaining differentiated selling prices.

The results obtained for ponds 2 and 3 show that selling the fish based on weight influences the duration of the production cycle and feed consumption (Table 5). Normally, after fish grows, feed conversion rate decreases, thus increasing production costs. On the other hand, larger fish may be better accepted by the consumer market, which once again highlights the need for technical and economical evaluation of commercial selling weight for each species and duration of production cycle, to determine the feasibility of the activity in the short and long term.

Average survival rate for the studied fish ponds was $43.6 \%$, which is considered relatively low, compared with other studies (Kubitza, 2003; Izel \& Melo, 2004). This result did not seem to significantly influence total average production cost, probably because the losses occurring in the juvenile phase when feed intake is low, and due to low purchase price of larvae and juveniles practiced when large quantities are bought.

Ponds 3, 4, 5, 6 and 8 displayed high productivity and good PI when rearing round fish (Table 5). However, the comparison of these indicators between ponds shows a proportional relationship between them. This can be visualized by comparing the results of ponds 4 and 5 . And it is even more evident when comparing ponds 2, 7 and 9, when the high productivity achieved in pond 2 translated into the lowest PI. The PI stems not only from increasing productivity and gross revenue, but also from better FC and/or higher survival rates (lower average cost) combined with shorter production cycles (lower average fixed cost).

Due to the differences that can be seen between economic indicators (Tables 4 and 5), it became interesting to examine some possible scenarios. If the production of each fish pond 
is similar to the average productivity of $5,544 \mathrm{~kg} \cdot \mathrm{ha}^{-1}$ per year, which was obtained for the ten fish ponds that were studied individually (Table 5), GMI and PI indicators would increase from $24.2 \%$ to $66 \%$ and from $1.89 \%$ to $55 \%$, respectively. However, proper planning is necessary.

\section{Conclusions}

The farming of round fish in large systems is economically feasible. The studied fish-farm displays the favorable conditions necessary to improve the performance and economic indicators above the values achieved until now. However, it is necessary to reproduce the breeding techniques and performance indicators achieved in few ponds to the entire farm. In addition, the differences observed in total costs depending on fish final weight lead to the conclusion that selling price as a function of weight class is one factor that is going to be relevant in the future of fish commerce and should be further investigated.

\section{Acknowledgments}

The authors express their gratitude to Casa do Peixe for providing the data used in this study and to Fundação de Amparo à Pesquisa do Estado de Mato Grosso - FAPEMAT, for the financial support.

\section{References}

ANDRADE, R.L.B.; WAGNER, R.L.; MAHL, I. et al. Custos de produção de tilápia (Oreochromis niloticus) em um modelo de propriedade da região oeste do estado do Paraná, Brasil. Ciência Rural, v.35, n.1, p.198-203, 2005.

AYROSA, L.M.S; ROMAGOSA, E.; REZENDE, D.M.M. et al. Custos e rentabilidade da produção de juvenis de tilápia-do-nilo em tanques-rede utilizando-se diferentes densidades de estocagem. Revista Brasileira de Zootecnia, v.40, n.2, p.231-239, 2011.

BARROS, A.F.; MARTINS, M.E.G.; SOUZA, O.M. Caracterização da piscicultura na microrregião da Baixada Cuiabana, Mato Grosso, Brasil. Boletim do Instituto de Pesca, v.37, n.3, p.261-273, 2011.

BARROS, A.F.; CAMPOS, C.M.; REDONDO, M.A.S. et al. Custo de produção da criação de surubins Pseudoplatystoma spp. alimentados com diferentes rações comerciais. In: CYRINO, J.E.P.; FURUYA, W.M.; RIBEIRO, R.P. et al. (Eds.) Tópicos especiais em biologia aquática e aquicultura III. Jaboticabal: Sociedade Brasileira de Aquicultura e Biologia Aquática, 2010. p.35-44.

DIÁRIO OFICIAL. [2006] Superintendência da Imprensa Oficial do Estado de Mato Grosso. Decreto-Lei Estadual no 8.464, de 04 de abril de 2006. Dispõe, define e disciplina a piscicultura no Estado de Mato Grosso e dá outras providências. Diário Oficial, Cuiabá, nº 23.468, p.1, 04 de abr. 2006.

EL-SAYED, A. Effects of stocking density and feeding levels on growth and feed efficiency of nile tilapia Oreochromis niloticus L.) fry. Aquaculture Research, v.33, p.621-626, 2002.
FIRETTI, R.; SALES, D.S. Lucro com tilápia é para profissionais ANUALPEC: Anuário da Pecuária Brasileira, São Paulo, 2007. p.285-286.

FURLANETO, F.P.B.; ESPERANCINI, M.S.T. Estudo da viabilidade econômica de projetos de implantação de piscicultura em viveiros escavados. Informações Econômicas, v.39, n.2, p.5-11, 2009.

FURLANETO, F.P.B.; ESPERANCINI, M.S.T.; BUENO, O.C. et al Análise quantitativa das pisciculturas da região paulista do Médio Paranapanema. Informações Econômicas, v.38, n.10, p.35-44, 2008.

FURLANETO, F.P.B.; AYROZA, D.M.M.R.; AYROZA, L.M.S. Custo e rentabilidade da produção de tilápia (Oreochromis spp.) em tanque-rede no Médio Paranapanema em tanque-rede no Médio Paranapanema, estado de São Paulo, Safra 2004/05. Informações Econômicas, v.36, n.3, p.63-69, 2006.

GOMES, L.C.; BALDISSEROTTO, B.; SENHORINI, J.A. Effect of stocking density on water quality, survival, and growth of larvae of matrinxã, Brycon cephalus (Characidae), in ponds. Aquaculture, v.183, p.73-81, 2000.

IZEL A.C.U.; MELO, L.A.S. Criação de tambaqui (Colossoma macropomum) em tanques escavados no Estado do Amazonas. Brasília: Embrapa, 2004. 14p. (Documentos, 32).

JOMORI, R.K.; CARNEIRO, D.J.; MALHEIROS, E.B. et al. Economic evaluation of Piaractus mesopotamicus juvenile production in different rearing systems. Aquaculture, n.243, p.175-183, 2005.

KUBITZA, F. Peixes Nativos: saiba como assegurar maior sobrevivência, encurtar o período de engorda e aproveitar bem os seus viveiros. Revista Panorama da Aquicultura, n.78, p.54-61, 2003.

MARTIN, N.B.; SCORVO FILHO, J.D.; SANCHES, E.G. et al. Custos e retornos na piscicultura em São Paulo. Informações Econômicas, v.25, n.1, p.9-47, 1995.

MARTIN, N.B.; SERRA, R.; OLIVEIRA, M.D.M. et al. Sistema integrado de custos agropecuários - CUSTAGRI. Informações Econômicas, v.28, n.1, p.7-28, 1998.

MARTINS, M.I.E.G.; BORBA, M.M.Z. Custo de produção. Jaboticabal: Fcav/Unesp, 2008. 22p.

MELO, J.S.C.; PEREIRA, J.A. Crescimento do híbrido tambacu (fêmea de Colossoma macropomum x macho de Piaractus mesopotamicus) em criação intensiva. Boletim Técnico do CEPTA, v.7, p.59-75, 1994.

MINISTÉRIO DA PESCA E AQUICULTURA - MPA 2010 Produção pesqueira e aquícola: Estatística 2008 e 2009. Available at: <http://www.mpa.gov.br/mpa/seap/Jonathan/mpa3/dados/2010/ Docs/Caderno\%20 Consolidação \%20 dos\%20dados \% 20 estatiscos\%20final\%20curvas\%20\%20completo.pdf $>$. Accessed on: Mar. 10, 2011.

SCHMITTOU, H.R. Produção de peixes em alta densidade em tanques rede de pequeno volume. Campinas: Mogiana Alimentos e Associação Americana de Soja, 1997. 78p.

SCORVO FILHO, J.D.; PINTOS, C.S.R.M.; VERANI, J.R. et al. Custo operacional de produção da criação de tilápia vermelha da Flórida e Tailandesa em tanques rede de pequeno volume. Informações Econômicas, v.36, n.10, p.71-79, 2006.

SCORVO FILHO, J.D.; MARTINS, M.I.G.E.; FRASCA-SCORVO, C.M.D. Instrumento para análise da competitividade na piscicultura. In: CYRINO, J.E.P.; URBINATI, E.C.; FRACALOSI, D.M et al. (Eds.) Tópicos especiais em piscicultura de água doce tropical intensiva. São Paulo: TecArt, 2004. p.517-533.

SCORVO FILHO, J.D.; MARTIN, N.B.; AYROZA, L.M.S. Piscicultura em São Paulo: custos e retornos de diferentes sistemas de produção na safra 1996/97. Informações Econômicas, v.28, n.3, p.41-62, 1998.

VERA-CALDERÓN, L.E.; FERREIRA, A.C.M. Estudo da economia de escala na piscicultura em tanque-rede, no estado de São Paulo. Informações Econômicas, v.34, n.1, p.7-17, 2004. 